\title{
Devetdeset let rusistke in frazeologinje Antice Menac
}

\author{
Jurij Rojs
}

Cobiss: 1.24

Akademikinja Antica Menac je osrednja osebnost hrvaške rusistike v 20. stoletju. Kar pomeni Rajko Nahtigal za Slovence, to je Antica Menac za Hrvate in južnoslovanske ter - širše gledano - za evropske in neevropske narode.

Rodila se je 11. julija 1922 v Splitu, kjer je maturirala leta 1940. Na Filozofski fakulteti Vseučilišča v Zagrebu je diplomirala iz slavistike (A-predmet: Ruski jezik in književnost, B-predmet: Hrvaški jezik s staro cerkveno slovanščino). Med študijem je delala kot korektorica, lektorica in novinarka pri časopisu Slobodna Dalmacija. Po končanem študiju se je zaposlila kot urednica pri založbi Glas rada, kjer je urejala knjige ruskih in hrvaških avtorjev. Asistentka profesorja Stjepana Ivšića je postala leta 1949. Leta 1957 je bila šest mesecev na specializaciji v Moskvi, kjer se je posvečala zlasti ruski skladnji in fonetiki. Doktorsko disertacijo Sklonske in predložnosklonske zveze s časovnim pomenom v hrvaškem in ruskem jeziku je obranila leta 1959. Na Filozofski fakulteti v Zagrebu je bila Antica Menac izvoljena v tele nazive: $1961 \mathrm{v}$ naziv docentka, 1966 izredna profesorica, 1973 redna profesorica. Štiriindvajset let je bila predstojnica Katedre za ruski jezik. Upokojila se je leta 1985.

V Jugoslovanski (zdaj Hrvaški) akademiji znanosti in umetnosti je leta 1975 postala članica sodelavka, leta 1981 izredna članica in leta 1988 redna članica.

V središču znanstvenega zanimanja Antice Menac so fonetika, skladnja, kontrastivno jezikoslovje, frazeologija in kontaktno jezikoslovje. S svojimi referati je sodelovala na številnih znanstvenih srečanjih na Hrvaškem in v tujini. Njena znanstvena dela so objavljena v hrvaških in tujih strokovnih revijah v hrvaškem, ruskem, nemškem, angleškem, poljskem in češkem jeziku. Leta 1973 je imela uvodni referat z naslovom Kontrastivno proučevanje jezika in teorija učbenikov na kongresu Mednarodne zveze predavateljev ruskega jezika in književnosti (MAPRJaL) v Varni (Bolgarija).

V sedemdesetih letih prejšnjega stoletja je v hrvaških strokovnih revijah objavila prve prispevke o hrvaški frazeologiji, ki so pomenili začetek zanimanja za to lingvistično disciplino na Hrvaškem. Hrvaško frazeološko problematiko postavlja v kontekst frazeologije drugih slovanskih jezikov (v prvi vrsti ruskega) in tudi neslovanskih. Prav zato imamo Antico Menac za znanstvenico, ki je položila temelje zagrebške frazeološke šole. Njeni poglavitni prispevki na to temo so objavljeni v njeni knjigi Hrvatska frazeologija (2007). 
V okviru hrvaške leksikografije in frazeografije imamo njeno delo za pionirsko. V soavtorstvu z Allo P. Koval je sestavila prvi (in doslej edini) Ukrajinsko-hrvatski ili srpski in hrvatsko ili srpsko-ukrajinski rječnik (1979). Bogato frazeološko gradivo je zajeto v slovarju z naslovom Rusko-hrvatski ili srpski frazeološki rječnik 1-2 (1979-1980), sledila je serija Mali frazeološki rječnici (1985-1998), nato pa obsežen Hrvatski frazeološki rječnik (2003) in Hrvatsko-ruski frazeološki rječnik (2011). Pri teh slovarjih je akademikinja Antica Menac sodelovala kot soavtorica in $\mathrm{v}$ večjem delu kot urednica.

Z Rudolfom Filipovićem je proučevala anglicizme $\mathrm{v}$ hrvaškem in ruskem jeziku. Objavila je več razprav (v soavtorstvom z Rudolfom Filipovićem ali samostojno), v katerih analizira tipe adaptacij anglicizmov $\mathrm{v}$ teh dveh slovanskih jezikih. Za področje kontaktnega jezikoslovja je posebej pomembna njuna monografija Engleski element u hrvatskom i ruskom jeziku (2005). V zadnjem času Antica Menac piše o rusizmih v hrvaškem jeziku in je soavtorica monografije Hrvatski jezik u dodiru s europskim jezicima: prilagodba posuđenica (2005).

Posebej pomembno je njeno delo z učbeniki ruskega jezika. V šestdesetih letih prejšnjega stoletja je objavila dva učbenika ruskega jezika po avdiovizualni globalno-strukturalni metodi Petra Guberine in Paula Rivenca, ki nista izšla samo v Zagrebu, temveč še v Parizu, Londonu, New Yorku in Stockholmu. Vsebujeta pregled ruske slovnice, vaje in slovar. Poleg tega je napisala več srednješolskih učbenikov ruskega jezika (po njih smo v šestdesetih in v začetku sedemdesetih let poučevali ruski jezik na slovenskih gimnazijah - dijaki so se na republiških tekmovanjih iz znanja ruščine dobro odrezali), učbenik za osnovne šole in še dva priročnika za študente rusistike.

Velik del svojega ustvarjalnega polstoletja je Antica Menac posvetila prevajanju. Prevedla je vrsto proznih del ruskih poetov in pisateljev, še posebej pa je treba poudariti zelo kakovostne prevode ukrajinske poezije. Dolgoletno prevajanje ukrajinske poezije je zaokroženo v zbirki prevodov Ukrajinska lirika (1998), ki jo je hkrati uredila in napisala spremno besedo $\mathrm{z}$ opombami.

Uredila je nekaj knjig prevodov ruske proze, zbornikov, lepo število frazeoloških slovarjev (pri katerih je istočasno tudi soavtorica). Dolga leta je bila članica uredništva izdaj Strani jezici in Filologija ter članica uredniškega odbora revije Russkij jazyk za rubežom.

Antica Menac je bila vodja nekaj znanstvenih projektov. V okviru Zavoda za lingvistiko Filozofske fakultete Vseučilišča v Zagrebu je vodila naslednje projekte: Leksikografsko delo na področju ruskega in ukrajinskega jezika, Raziskovanje frazeologije $\mathrm{v}$ ruskem in hrvaškem knjižnem jeziku, Hrvaška frazeološka problematika, Kontrastivna analiza hrvaškega in ruskega knjižnega jezika, Kontrastivno proučevanje hrvaškega jezika glede na tuje jezike. Zdaj v okviru Zavoda za lingvistična raziskovanja HAZU vodi projekt Proučevanje hrvaške frazeologije.

Bila je podpredsednica Hrvaškega filološkega društva, članica uprave in predsednica njegove Sekcije za tuje jezike, podpredsednica Zveze slavističnih društev Jugoslavije ter Zveze društev za tuje jezike in književnosti Jugoslavije. Je ena od ustanoviteljev MAPRJaL, članica njene uprave, šest let je v njej opravljala funkcijo 
podpredsednice. Dolga leta je bila predsednica Mednarodne komisije za problematiko učbenikov ruskega jezika pri MAPRJaL-u.

Za svoje delo je bila štirikrat nagrajena: Mednarodna zveza predavateljev ruskega jezika in književnosti ji je leta 1979 podelila medaljo A. S. Puškina, 1980 je dobila nagrado mesta Zagreba (za Ukrajinsko-hrvatski ili srpski in hrvatsko ili srpsko-ukrajinski rječnik), 1981 je prejela republiško nagrado Božidarja Adžija (za Rusko-hrvatski ili srpski frazeološki rječnik), leta 2008 pa visoko državno odlikovanje Republike Ukrajine (za zasluge v razvoju hrvaške ukrajinistike).

Iz bibliografije Antice Menac navajamo njene knjige, slovarje ter učbenike in priročnike, neupoštevane pa ostajajo znanstvene in strokovne objave, uredniško delo in prevodi.

\section{Knjige}

Ruski jezik na pločama: izgovor i intonacija $s$ recitacijama, Zagreb: Institut za fonetiku Filozofskog fakulteta Sveučilišta u Zagrebu, 1958 (Acta Instituti Phonetici 7).

Ukrajinska lirika, Zagreb: Matica hrvatska, 1998.

Uredila, prevedla iz ukrajinščine, napisala spremno besedo in opombe.

Engleski element u hrvatskom i ruskom jeziku, Zagreb: Školska knjiga, 2005.

Soavtor Rudolf Filipović.

Hrvatska frazeologija, Zagreb: Knjigra, 2007.

Frazeologija splitskog govora s rječnicima, Zagreb: Institut za hrvatski jezik i jezikoslovlje, 2011.

Soavtorica Mira Menac-Mihalić.

\section{Slovarji}

Rusko-hrvatski ili srpski frazeološki rječnik 1-2, Zagreb: Školska knjiga, 1979-1980.

Soavtorji Tatjana Korać - Milenko Popović-Miho Skljarov - Radomir Venturin - Renata Volos.

Ukrajinsko-hrvatski ili srpski rječnik i Hrvatsko ili srpsko-ukrajinski rječnik, Zagreb: Sveučilišna naklada Liber, 1979.

Soavtorica Alla P. Koval.
Hrvatskosrpsko-rusko-ukrajinski frazeološki rječnik, Zagreb: Zavod za lingvistiku Filozofskog fakulteta Sveučilišta u Zagrebu, 1985 (Mali frazeološki rječnici 1).

Soavtorica Raisa I. Trostinska.

Hrvatskosrpsko-češko-slovački frazeološki rječnik, Zagreb: Zavod za lingvistiku Filozofskog fakulteta Sveučilišta u Zagrebu, 1986 (Mali frazeološki rječnici 2).

Soavtorici Dubravka Dorotić Sesar - Renata Kuchár.

Hrvatskosrpsko-poljski frazeološki rječnik, Zagreb: Zavod za lingvistiku Filozofskog fakulteta Sveučilišta u Zagrebu, 1986 (Mali frazeološki rječnici 3).

Soavtorica Neda Pintarić.

Hrvatskosrpsko-talijanski frazeološki rječnik, Zagreb: Zavod za lingvistiku Filozofskog fakulteta Sveučilišta u Zagrebu, 1988 (Mali frazeološki rječnici 5).

Soavtorica Zorica Vučetić.

Hrvatskosrpsko-francuski frazeološki rječnik, Zagreb: Zavod za lingvistiku Filozofskog fakulteta Sveučilišta u Zagrebu, 1988 (Mali frazeološki rječnici 6).

Soavtor Krešimir Blaževac.

Hrvatsko-slovenski frazeološki rječnik, Zagreb: Zavod za lingvistiku Filozofskog fakulteta Sveučilišta u Zagrebu, 1992 (Mali frazeološki rječnici 7).

Soavtor Jurij Rojs. 
- Hrvatsko-rusko-ukrajinski frazeološki rječ[- nik: II. izdanje, Zagreb: Zavod za lingvistiku Filozofskog fakulteta Sveučilišta u Zagrebu, 1993 (Mali frazeološki rječnici 9).

Soavtorica Raisa I. Trostinska.

Hrvatsko-talijanski frazeološki rječnik, Zagreb: Zavod za lingvistiku Filozofskog fakulteta Sveučilišta u Zagrebu, ${ }^{2} 1995$ (Mali frazeološki rječnici 10).

Soavtorica Zorica Vučetić.

Hrvatsko-češko-slovački frazeološki rječnik s indeksom čeških i slovačkih frazema:

- II. prošireno i dopunjeno izdanje, Zagreb: Zavod za lingvistiku Filozofskog fakulteta Sveučilišta u Zagrebu, 1998 (Mali frazeološki rječnici 14).

Soavtorici Dubravka Dorotić Sesar - Renata Kuchár.

Hrvatski frazeološki rječnik, Zagreb: Naklada Ljevak, 2003.

Soavtorja Željka Fink-Arsovski - Radomir Venturin.

Hrvatsko-ruski frazeološki rječnik - Kazalo hrvatskih i ruskih frazema, Zagreb: Knjigra, 2011.

Soavtorji Željka Fink-Arsovski - Irina Mirnova Blažina - Radomir Venturin.

\section{Učbeniki in priročniki}

Méthode Audiovisuelle de Russe premier degré. selon les principes SGAV définis par $P$. Guberina et P. Rivenc, Paris - Bruxelles Montréal: Didier, 1962.

Russian Audiovisual, London: Harrap, 1962.

Russian Audiovisual, New York: Chilton, 1962.

Ruski: audiovizuelna metoda 1, ur. Peter Guberina - Paul Rivenc, Zagreb: Jugoton Didier, 1963.
Priručni rječnik uz AV metodu, Zagreb, 1963.

Audiovisuell ryska, Stockholm: Svenska Bokforlaget/Norstedt, 1964.

Ruski: audiovizuelna metoda II, ur. Petar Guberina - Paul Rivenc, Zagreb: Jugoton Didier, 1964.

Grammaire et Léxique, Paris: Didier, 1965.

Zbornik vježbi iz ruske fonetike: priručnik za studente rusistike, Zagreb: Sveučilište u Zagrebu, 1965.

Давайте говорить и читать по-русски 1 : početnica ruskog jezika za prvi razred gimnazije (prva godina učenja), Zagreb: Skolska knjiga, 1966.

Méthode Audiovisuelle de Russe, deuxième degré, selon les principes SGAV définis par $P$. Guberina et P. Rivenc, Paris - Bruxelles Montréal: Didier, 1967.

Давайте говорить и читать по-русски 2: vježbenica ruskog jezika za II. razred gimnazije (druga godina učenja), Zagreb: Školska knjiga, 1967.

Давайте говорить и читать по-русски 3 : vježbenica ruskog jezika za III. razred gimnazije (tré́a godina učenja), Zagreb: Školska knjiga, 1968.

Давайте говорить и читать по-русски 4: vježbenica ruskog jezika za IV. razred gimnazije (četvrta godina učenja), Zagreb: Školska knjiga, 1969.

Лексика и фразеология современного русского литературного языка, Zagreb: Sveučilište u Zagrebu, 1971.

Soavtor M. I. Iljaš.

Говорите с нами: udžbenik ruskog jezika za VII. razred osnovne škole, Zagreb: Školska knjiga, 1979.

Soavtor Miho Skljarov. 
Antica Menac je znanstvenica izredno širokega obzorja. V njenem odnosu do soljudi je treba pisati besedo Človek z veliko začetnico. Kot mentorica pri mnogih magistrskih in doktorskih delih je s širino svoje duše globoko prisluhnila različnim vprašanjem raziskovalcev ruske frazeologije. Magistrande in doktorande je z lepo besedo spodbujala $\mathrm{k}$ neizmernemu bogastvu ruske frazeologije, hkrati pa je bila zahtevna, a vselej človeško topla. Svojim študentom je dajala na vpogled obsežno študijsko gradivo, obenem pa pazila, da niso skrenili z začrtane poti.

Ob 90. obletnici ji želimo veliko zdravih in ustvarjalnih let. Kdor se ukvarja $\mathrm{s}$ študijem ruskega jezika, se prej ali slej sreča z njenimi znanstvenimi dognanji na področju lingvistike - slavistike, katere korenine segajo do globin slovanske duše. Naj ji sije prijazno sonce! 